\title{
Survival of Rice Non-embryogenic Callus Cells after Cryopreservation in Liquid Nitrogen by Vitrification
}

\author{
Katsumi WATANABE*,**, Akira KURIYAMA*, Fumio KAWAI* and Masao KANAMORI*
}

Received 19 August 1997; accepted 19 September 1997

Cryopreservation of plant cells in liquid nitrogen $\left(\mathrm{LN}_{2}\right)$ is an important tool for the conservation of plant genetic resources. Recently, a vitrification technique is used successfully for the cryopreservation of various types of meristems and embryogenic cells $[1,2]$. The vitrification technique is a simple procedure compared with the conventional method that needs expensive controlled freezing equipment for prefreezing to about $-40^{\circ} \mathrm{C}[3]$. It permits cells to be cryopreserved by the direct transfer into $\mathrm{LN}_{2}$ without prefreezing. However, few studies have examined cryopreservation of cultured non-embryogenic cells by vitrification technique [4]. It is reported that carrot non-embryogenic and embryogenic callus cells are different in their morphological and physiological natures [5]; embryogenic cells are small and compact, while non-embryogenic cells are larger. In general, large cells are sensitive to dehydration stress [4]. In the cryopreservation of cultured plant cells, cell dehydration prior to quenching in $\mathrm{LN}_{2}$ is required for the survival of cells after storage in $\mathrm{LN}_{2}$. These suggest that non-embryogenic cells might be more sensitive to dehydration stress, and the cryopreservation of them seem to be difficult. However, cryopreservation of non-embryogenic cells by vitrification technique is needed for the routine conservation of cell lines that are obtained by cell fusion or cell selection without genetic changes. In this paper, we evaluate the potential of the vitrification technique for the cryopreservation of non-embryogenic callus cells of rice.

Rice (Oryza sativa L. cv Nihonbare) non-embryogenic callus cells were subcultured on Linsmaier and Skoog (LS) agar $(0.9 \mathrm{w} / \mathrm{v} \%)$ medium [6] containing $10 \mu \mathrm{M}$ of 2,4-dichlorophenoxyacetic acid at $27^{\circ} \mathrm{C}$ under fluorescent light every two weeks. Callus cells at the logarithmic growth phase $(5 \sim 7$ days after inoculation) were used for experiments.

For vitrification, callus cells were suspended into LS liquid medium. Five hundred $\mu l$ (settled cell volume) of cells, containing small cell aggregates $(<1 \mathrm{~mm}$ in diameter), was loaded in $2.5 \mathrm{~m} l$ of LS liquid medium

\footnotetext{
* Interdisciplinary Research Institute of Environmental Sciences, Itsutsuji-dori Hichihon-matsu, Kyoto 602-8317, Japan

** Faculty of Food and Nutrition, Department of Agriculture, Kinki University, 3327-204, Naka-machi, Nara 631-8505, Japan
}

containing $1.5 \mathrm{M}$ dimethylsulfoxide (DMSO) at room temperature for $20 \mathrm{~min}$. The loaded cells were dehydrated with $2.5 \mathrm{~m} l$ of a vitrification solution $(50 \mathrm{w} /$ $\mathrm{v} \%$ glycerol $+50 \mathrm{w} / \mathrm{v} \%$ sucrose) on ice for 5 to 30 min, and then immersed into $\mathrm{LN}_{2}$. After the storage in $\mathrm{LN}_{2}$ for 7 days, the stored cells were thawed in $60^{\circ} \mathrm{C}$ water bath for $c a .40 \mathrm{sec}$ until the ice in the tube had just melted, and then unloaded in $5 \mathrm{~m} l$ of LS liquid medium or several different sorbitol solutions at room temperature for $30 \mathrm{~min}$. Unloaded cells were used for viability assay.

Cell survival was assayed by fluorescein diacetate (FDA) staining [7] and regrowth test, and was expressed as a percentage of the untreated control cells. For the regrowth test, $500 \mu l$ (settled cell volume) of unloaded cells was cultured on $20 \mathrm{~m} l$ of a semi-solid $(0.6 \mathrm{w} / \mathrm{v} \%$ agar $)$ culture medium in a petri dish under the same conditions mentioned above for up to 2 months.

The effects of unloading solution and dehydration time on the survival after vitrification [1-3] were studied. Loaded and dehydrated cells were unloaded in different solutions. The FDA values of cells unloaded in LS liquid medium, 0.5 M, 1.0 M, and 1.5 M sorbitol solution were $36 \pm 7 \%, 51 \pm 11 \%, 45 \pm 8 \%$, and $49 \pm 5 \%$, respectively. Unloading in a hypotonic solution (LS liquid medium) reduced cell viability. 0.5 $\mathrm{M}$ sorbitol solution which gave the highest value was used as an unloading solution in the following experiments. The FDA values of cells stored in $\mathrm{LN}_{2}$ after dehydration for $5,10,20$, and $30 \mathrm{~min}$ were $36 \pm 3 \%$, $37 \pm 9 \%, 40 \pm 8 \%$, and $37 \pm 12 \%$, respectively. Five to thirty minutes of dehydration time did not affect the cell survival. After the storage in $\mathrm{LN}_{2}$, only a few of the vitrified cells formed colonies during post-thaw culture on a semi-solid medium for 2 months. The survival of rice non-embryogenic callus cells after the vitrification was lower than that after the conventional method (Table 1). However, the growth rate of the callus cells subcultured from the colonies formed on the LS agar medium after 1 month was similar to those of the untreated control callus cells and the callus cells subcultured from the colonies formed from program-freezed cells in the same manner (Fig. 1).

Vitrification is a suitable method for the cryopreservation of plant cells because it permits cells to be 
Table 1. Survival of rice non-embryogenic callus cells after cryopreservation in $\mathrm{LN}_{2}$ by different protocols.

\begin{tabular}{|c|c|c|}
\hline \multirow{2}{*}{ Protocol } & \multicolumn{2}{|c|}{ Survival(\%) } \\
\hline & FDA value & Regrowth $^{\mathrm{a}}$ \\
\hline Conventional slow freezing ${ }^{b}$ & $61 \pm 10$ & $35 \pm 15$ \\
\hline Vitrification $^{c}$ & $37 \pm 6^{*}$ & $5 \pm 2^{*}$ \\
\hline \multicolumn{3}{|c|}{$\begin{array}{l}\text { The means }( \pm \mathrm{SD}) \text { of six repeated experiments are presented. } \\
\text { Differences between means were analyzed by } t \text {-tests. }{ }^{*} \mathrm{P}=0.01 \text {. } \\
\text { a Fresh weights were measured after } 15 \text { days of post-thaw culture. } \\
{ }^{\mathrm{b}} \mathrm{Cells} \text { were cooled at } 1^{\circ} \mathrm{C} / \mathrm{min} \text { to }-30^{\circ} \mathrm{C} \text { in the presence of } 5 \mathrm{v} / \mathrm{v} \% \\
\mathrm{DMSO}+10 \mathrm{w} / \mathrm{v} \% \mathrm{D} \text {-glucose in a programmed freezer, frozen in } \mathrm{LN}_{2} \text {, } \\
\text { and then were thawed rapidly, cultured on a semi-solid agar medium as } \\
\text { described previously [8]. } \\
{ }^{\mathrm{c} C e l l s ~ w e r e ~ l o a d e d ~ i n ~} 1.5 \mathrm{M} \text { DMSO at room temperature for } 20 \mathrm{~min} \text {, } \\
\text { dehydrated with } 50 \mathrm{w} / \mathrm{v} \% \text { glycerol }+50 \mathrm{w} / \mathrm{v} \% \text { sucrose on ice for } 20 \mathrm{~min} \text {, } \\
\text { immersed into } \mathrm{LN}_{2} \text {, and then unloaded in } 0.5 \mathrm{M} \text { sorbitol at room tempera- } \\
\text { ture for } 30 \text { min as described in text. }\end{array}$} \\
\hline
\end{tabular}

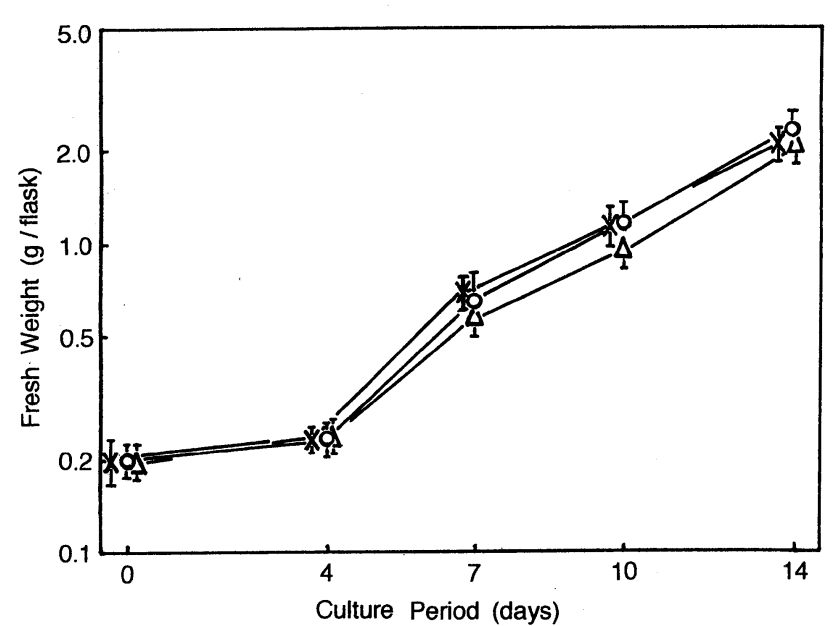

Fig. 1 Growth curve of rice non-embryogenic callus cells.

The means $( \pm S D)$ of five measurements are presented. $\bigcirc$; Untreated control cells, $\triangle$; Vitrified cells, $\times$; Program-freezed cells (Conventional method). Cells $(0.2 \mathrm{~g}$ fresh weight) were inoculated on $25 \mathrm{~m} l$ of the LS agar medium in a flask and incubated under the conditions as described in text.

cryopreserved by the direct transfer into $\mathrm{LN}_{2}$ without controlled slow freezing. A wide range of meristems and embryogenic cells are cryopreserved in $\mathrm{LN}_{2}$ by vitrification $[1,2]$. The survival of meristems and embryogenic cells after the vitrification is as high as the survival of them after the conventional method in many cases. However, the survival of rice non-embryogenic callus cells after the vitrification was lower than that after the conventional method (Table 1). Elimination of ammonium ion from post-thaw culture medium did not increase the viability of the vitrified rice non-embryogenic callus cells (unpublished data), although it increased the viability of the program- freezed cells [8]. Cell dehydration step prior to quenching in $\mathrm{LN}_{2}$ is required for the successful cryopreservation of plant cells. Cells are dehydrated in a concentrated vitrification solution in the vitrification technique instead of freeze-induced dehydration in the conventional method. These findings suggest that the dehydration stresses of the vitrification technique and the conventional method might differ, and non-embryogenic cells are more sensitive to the osmotic stress and/or the chemical toxicity resulting from the exposure to a concentrated vitrification solution, thus it is hard for non-embryogenic cells to survive after vitrification.

In conclusion, non-embryogenic rice callus cells were cryopreserved by the vitrification technique (Table 1). After cryopreservation, the cells grew vigorously in the same manner as the untreated control and the program-freezed cells (Fig.1). This study showed that the vitrification technique could be used for the cryopreservation of non-embryogenic cells as well as meristems and embryogenic cells. However, further studies are needed to improve the cell survival rate.

\section{References}

[1] Nishizawa, S., Sakai, A., Amano, Y., Matsuzawa, T., 1993. Plant Sci., 91: 67-73.

[2] Matsumoto, T., Sakai, A., Yamada, K., 1994. Plant Cell Rep., 13: 442-446.

[ 3 ] Langis, R., Schnabel, B., Earle, E. D., Steponkus, P. L., 1989. Cryo-Letters, 10: 421-428.

[4] Withers, L. A., 1985. In "Cryopreservation of Plant Cell and Organs” (ed. by Kartha, K. K.), p. 243-267, CRC Press, Boca Raton Florida.

[5] Kikuchi, A., Sato, S., Nakamura, N., Fujii, T., 1995. Plant Cell Rep., 14: 279-284. 
[6] Linsmaier, E. M., Skoog, F., 1965. Physiol. Plant., 18: 100-127.

[7] Widholm, J. M., 1972. Stain Technol., 47: 189-
194.

[ 8 ] Kuriyama, A., Watanabe, K., Ueno, S., Mitsuda, H., 1989. Plant Sci., 64: 231-235. 